\title{
Crushing of Mineral Particles by Control of Their Kinetic Energy
}

\author{
Elias Stamboliadis ${ }^{1}$, Dimitris Stamboliadis ${ }^{2}$, Kyriaki Kiskira ${ }^{3}$, Chukwudubem Emejulu ${ }^{4}$, \\ ${ }^{1,3,4}$ Technical University of Crete, ${ }^{2}$ Superior Technical Educational Institution of Piraeus
}

\begin{abstract}
The present paper studies the energy size relationship of minerals using a specially designed centrifugal crusher with rotation frequency control. The feed particles are accelerated by the rotating disc of the crusher and they crush on the opposite vertical wall having the predetermined specific kinetic energy. The mathematical modelling shows that the specific energy, energy per unit mass of the particles, is independent of their mass and is calculated to depend on the rotation frequency and the disc diameter. Crystalline limestone, marly limestone and serpentine samples are tested. The results obtained are used to present the energy-size relationship and to compare the crushing amenability of the rocks tested. A suggestion for further study is to derive the mathematical model of the breakage curves and to calculate the breakage energy for each size class using the model to be proposed.
\end{abstract}

Keywords: centrifugal crusher, kinetic energy, grindability, size-energy relationship

\section{INTRODUCTION}

The energy-particle size relationship is very important in mineral processing and in many cases it is difficult to assess. In ball mills, for instance, only a small part of the energy input is used for the size reduction of the particles. However, there are some laboratory techniques that allow a direct measurement of the energy provided for size reduction.

The most familiar laboratory technique is the drop weight, according to which the particle to be crushed, having a mass $m$, rests by its stable side on a solid horizontal metal surface and a metal hammer, of mass $M$, is allowed to drop vertically on it from a height $h$.

By the free fall, the initial potential energy $E_{p}=M \cdot g \cdot h$ of the hammer, at height $h$, is transformed into kinetic energy $E_{k}=M \cdot v^{2} / 2$ at the time of contact with the particle. Since $E_{p}=E_{k}$ one can calculate the energy provided for size reduction by measuring the mass $M$ of the hummer and its initial height $h$. Some recent developments allow the direct measurement of the impact velocity using high speed cameras (Tavares et al.) [1]. The drop weight technique is examined below in order to compare it to the technique of the centrifugal mill proposed in the present study.

Assume a spherical particle of $10 \mathrm{~mm}$ in diameter with density $2.7\left(\mathrm{~g} / \mathrm{cm}^{3}\right)$ that is to be crushed by a free falling hammer of $1 \mathrm{~kg}$ mass. If the specific energy to be applied on the particle is 3600 Joule per $\mathrm{kg}$ of the particle or 1 ( $\mathrm{kWh} / \mathrm{ton})$, then the hammer has to be raised at a height of $0.52 \mathrm{~m}$. At this point, the potential energy of the hummer is 5.09 Joule. The mass of the particle is $1.41 \mathrm{~g}$ and, consequently, the energy of the hammer corresponds to specific energy $3600(\mathrm{~J} / \mathrm{kg})$ of the particle, as demanded. In the case the particle is $20 \mathrm{~mm}$ in diameter, then either the mass of the hammer should be increased to $8 \mathrm{~kg}$ or it should be raised to $4.15 \mathrm{~m}$.

On the other hand, in the case one wishes to allow the particle drop by itself on a solid metal surface then, in the absence of atmospheric air, one should raise the particle at a height of $367 \mathrm{~m}$ in order to apply the same specific energy of $3600(\mathrm{~J} / \mathrm{kg})$. It should be noticed that this height is independent of the particle diameter and depends only on the specific energy required. It is obvious from the above calculations that it is not practical to accelerate a particle by means of gravity especially in the absence of air in order to control its kinetic energy.

In order to achieve an easier acceleration, the idea of the present study is to use a centrifugal force that is generated by a rotating disc and gives a kinetic energy to the particle at the moment it escapes from the disc and crushes on an opposite metal wall at a small distance from the periphery of the rotating disc. By controlling the rotation frequency of the disc one could easily control the kinetic energy of the particles at the moment they escape from the disc.

\section{DESCRIPTION OF THE CRUSHER}

The equipment used is a locally made centrifugal crusher described in detail by D. Stamboliadis [2]. It consists of a horizontal rotating disc, $500 \mathrm{~mm}$ in diameter, surrounded by a homocentric, cylindrical cell of $900 \mathrm{~mm}$ in diameter. The disc rotation axis is vertical and is linearly and directly connected to the axis of an electric motor through a cobbler. The rotation frequency of the motor and, consequently, of the disc is controlled by an inverter in the range of 700 to $2500 \mathrm{rpm}$. Radially on the disc, there are two symmetric, vertical blades that oblige any particle on the disc to rotate. The particles are introduced at the centre of the disc, through a vertical shaft, and are obliged to rotation by the radial blades. As a result of the rotation, the centrifugal force acts on the particles and drives them to the periphery of the disc along the blades. As the particles move from the centre to the periphery of the disc, their rotation velocity, which is vertical to the radius, increases continuously and so does the centrifugal force that gives them velocity on the direction of the radius. At the moment the particles reach the periphery of the disc, they escape with the two velocity components that are vertical to each other and equal in magnitude, as calculated below. Their resultant is the vector sum of the two velocities and its direction is at 45 degrees to the radius of the disc at the moment of escape. This means that the resultant velocity vector is not vertical to the 
homocentric cell surrounding the rotating disc and the particles will not crush on it at an angle of 90 degrees. In order to ensure that the particles leaving the disc will crush on a surface vertical to the direction of their velocity, the inner side of the surrounding cell is lined by blades of hard steel at an angle of 45 degrees to the radius. Figures 1 and 2 give an outside and inside view of the crusher.

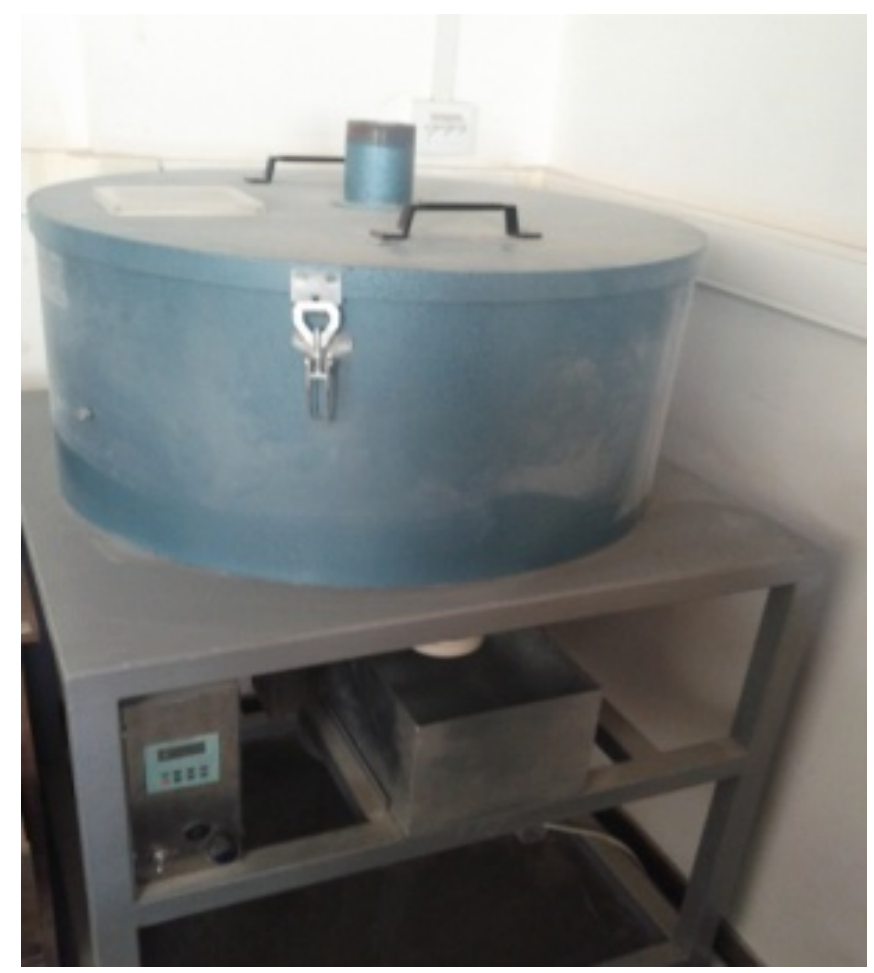

Fig. 1. External view of the crusher

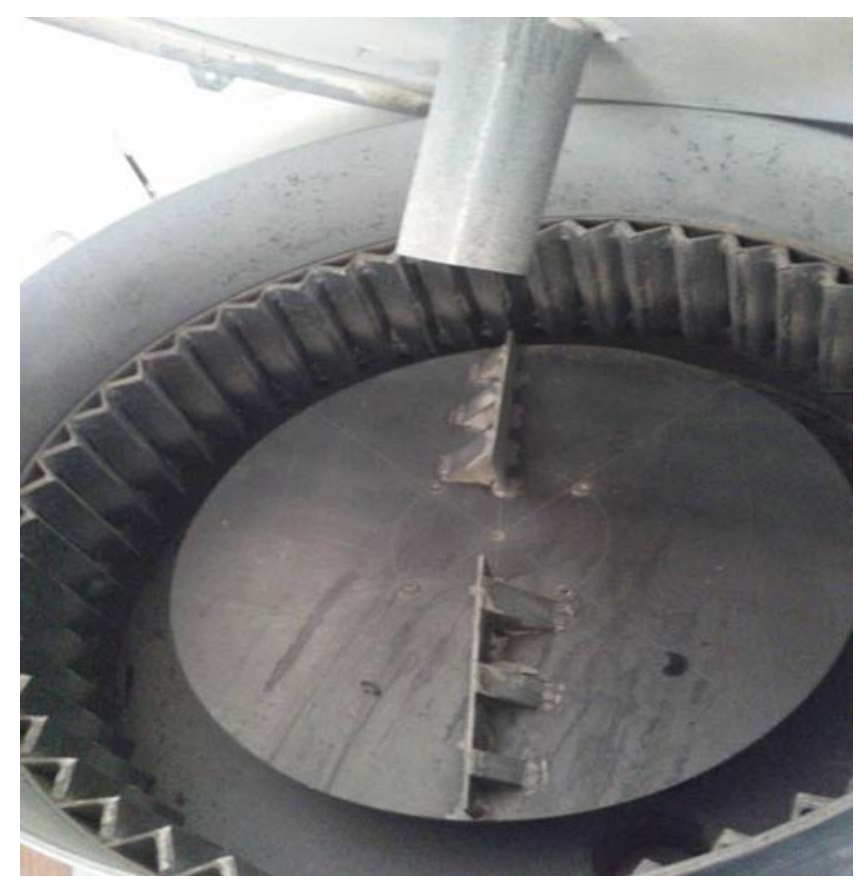

Fig. 2. Internal view of the crusher

\section{CALCUlation OF THE KinETIC ENERGY}

The radius of the disk is $R$, and two radial blades are fixed diametrically on the disc surface and oblige any particle on its surface to rotate at the same frequency $N$. Let a particle of mass $m$ be at a distance $r$ from the centre of rotation. The peripheral velocity $V_{p}$ at this point it given by Eq. 1:

$$
v_{p}=2 \cdot \pi \cdot r \cdot N
$$

A centrifugal force $F_{c}$ acts on the particle that is related to its peripheral velocity according to Eq. 2:

$$
F_{c}=\frac{m \cdot v_{p}^{2}}{r}
$$

The centrifugal force moves the particle to the perimeter with the acceleration calculated by Newton's law given by Eq. 3:

$$
F_{c}=m \cdot \gamma_{c}
$$

Substituting (1) and (2) into (3) one has Eq. 4:

$$
\gamma_{c}=(2 \cdot \pi \cdot N)^{2} \cdot r
$$

From the laws of motion, one has the relationship between the centrifugal velocity $V_{c}$, the time $t$ and the centrifugal acceleration given by Eq. 5, as well as the relationship between the centrifugal velocity, the time and the radius given by Eq. 6 :

$$
\begin{aligned}
& \frac{d v_{c}}{d t}=\gamma_{c} \\
& \frac{d r}{d t}=v_{c}
\end{aligned}
$$

Equating and deleting $d t$ from (5) and (6) one has Eq. 7:

$$
\frac{d v_{c}}{\gamma_{c}}=\frac{d r}{v_{c}} \quad \text { OR } \quad v_{c} \cdot d v_{c}=\gamma_{c} \cdot d r
$$

Substituting (4) into (7) one has the differential Eq. 8 that relates the centrifugal velocity to the radius, that is, the distance from the centre of the rotation:

$$
v_{c} \cdot d v_{c}=(2 \cdot \pi \cdot N)^{2} \cdot r \cdot d r
$$

The integration of (8) is given by Eq. 9:

$$
v_{c}=2 \cdot \pi \cdot N \cdot r+C
$$

For $r=0$ then $v_{c}=0$ and consequently $C=0$ 
At the moment when the particle escapes from the disc, $r$ $=\mathrm{R}$ and the centrifugal radial velocity is given by (10):

$$
V_{c}=2 \cdot \pi \cdot R \cdot N
$$

At the same moment, the peripheral velocity is given by Eq. 11 as being equal but vertical to the centrifugal velocity.

$$
V_{p}=2 \cdot \pi \cdot R \cdot N
$$

The vector sum of these two velocities is the actual escaping velocity $V$ that is calculated using Eq. 12:

$$
V^{2}=V_{c}^{2}+V_{p}^{2}
$$

Taking into consideration (10) and (11), the final velocity is given by Eq. 13 and has a direction of $45^{\circ}$ relative to the radius of the disc at the moment of escape.

$$
V=2 \cdot \sqrt{2} \cdot \pi \cdot R \cdot N \quad \text { or } \quad V=\sqrt{2} \cdot \pi \cdot D \cdot N
$$

where $\mathrm{D}$ is the disc diameter $D=2 R$.

The kinetic energy $E$ of a particle with velocity $V$ is given by Eq. 14:

$$
E=\frac{1}{2} \cdot m \cdot V^{2}
$$

Substituting (13) into (15), the kinetic energy of the particle at the escape point from the disc is given by Eq. 15:

$$
E=m \cdot(2 \cdot \pi \cdot R \cdot N)^{2} \text { or } E=m \cdot(\pi \cdot D \cdot N)^{2}
$$

The specific energy $e=E / m$ is then given by Eq. 16 and is independent of the particle mass:

$$
e=(2 \cdot \pi \cdot R \cdot N)^{2} \quad \text { or } \quad e=(\pi \cdot D \cdot N)^{2}
$$

Applying the above formula to the case described in the introduction one calculates that for the particular crusher, with a disc of $500 \mathrm{~mm}$ in diameter, the frequency required to achieve specific energy $\mathrm{e}=3600(\mathrm{~J} / \mathrm{kg})$ or the same 1 $(\mathrm{kWh} / \mathrm{ton})$ is $2293 \mathrm{rpm}$ and is independent of the size of the particle. This frequency is within the capacity of the machine manufactured.

\section{MATERIALS USED}

Three different rocks are used, namely: 1) crystalline limestone from the operating quarry of Hordaki near Chania, 2) marly limestone from the area of Akrotiri near Chania and 3) serpentine from the area of Mantoudi on the Island of Euboea, Greece. Mineralogical examination of the samples by XRD gives the results presented in Table 1, while the microscopic structure of the samples, which appears in polished sections, is depicted in Figures 3 to 5, respectively.

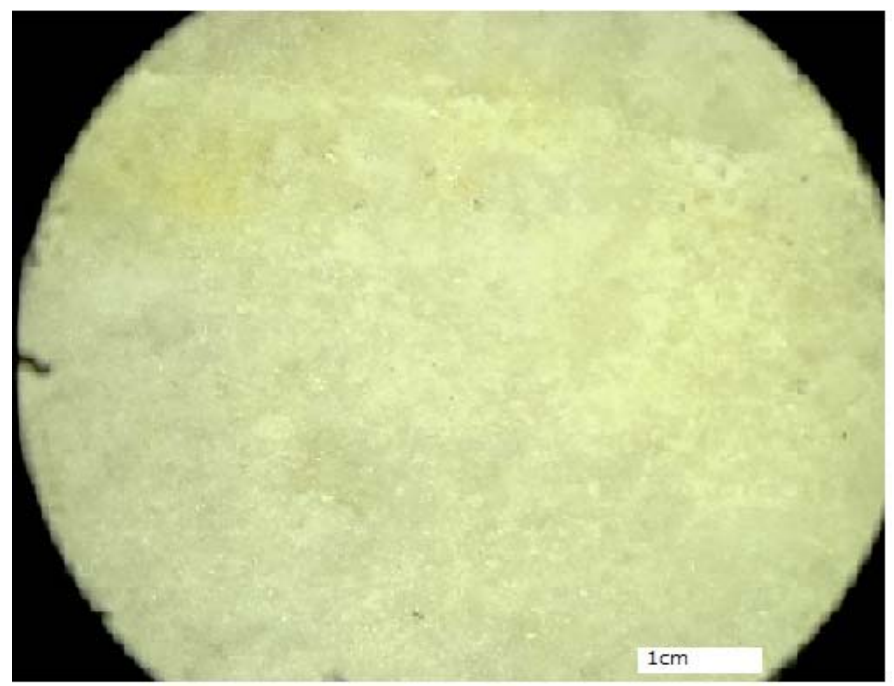

Fig. 3. Crystalline limestone

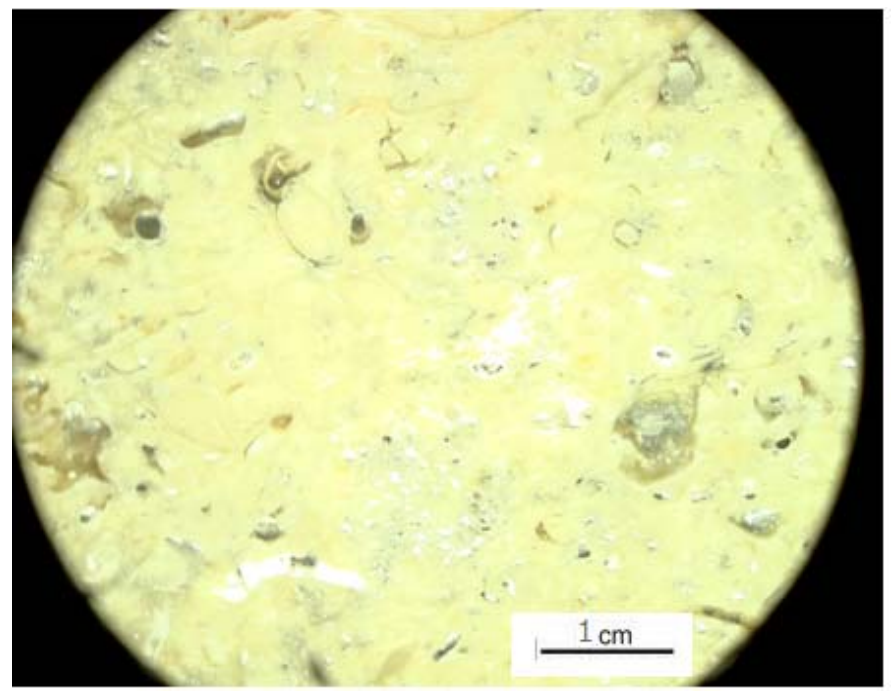

Fig. 4. Marly limestone

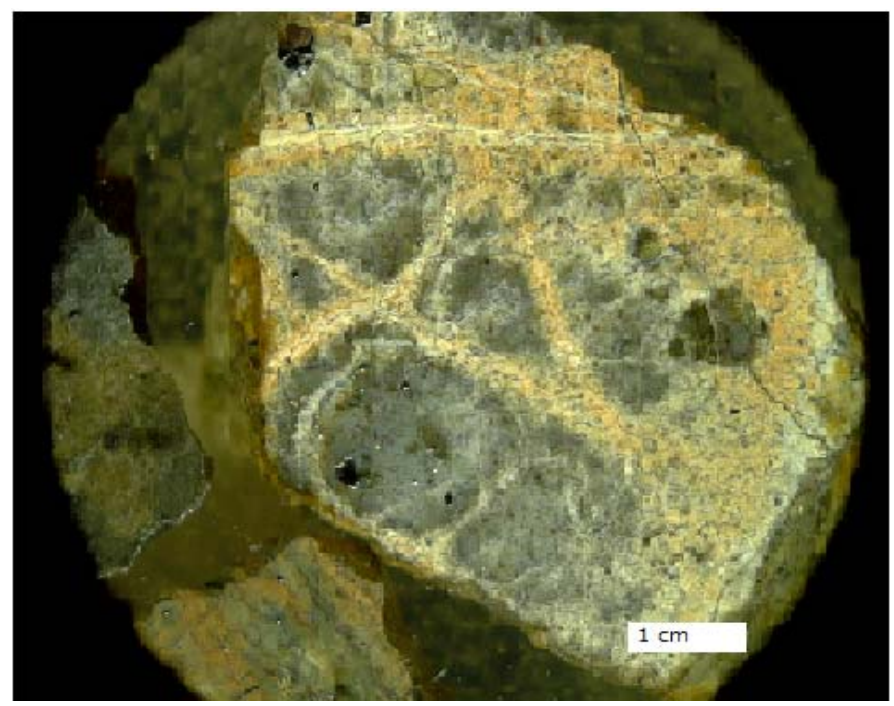

Fig. 5. Serpentine 
Table 1

Minerals Identified in the Samples by XRD

\begin{tabular}{|c|c|c|c|}
\hline & $\begin{array}{c}\text { Crystalline } \\
\text { limestone }\end{array}$ & $\begin{array}{c}\text { Marly } \\
\text { limestone }\end{array}$ & Serpentine \\
\hline $\begin{array}{c}\text { Main } \\
\text { minerals }\end{array}$ & Calcite & Calcite & $\begin{array}{c}\text { Lizardite } \\
\text { Clinochrysotile }\end{array}$ \\
\hline $\begin{array}{c}\text { Minority } \\
\text { minerals }\end{array}$ & Dolomite & $\begin{array}{c}\text { Dolomite } \\
\text { Aluminium } \\
\text { silicates }\end{array}$ & Clinochlore Dolomite \\
\hline
\end{tabular}

Crystalline limestone appears to be homogeneous, while marly limestone contains pores as well as inclusions of impurities of silicate minerals. Serpentine is not homogeneous and the particle is made of smaller crystals in the form of islands surrounded by a more or less inhomogeneous binder that appears to be weathered and weaker than the healthy crystals.

\section{TECHNICAL PROCEDURE}

The material tested (about $30 \mathrm{~kg}$ each) was crushed to $30 \mathrm{~mm}$ using a laboratory jaw crusher. The material was then classified into the following size fractions of very narrow size range $(16-22.4 \mathrm{~mm}),(8-11.2 \mathrm{~mm}),(4-5.6 \mathrm{~mm}),(2-2.8 \mathrm{~mm})$ and $(1-1.4 \mathrm{~mm})$. The geometric average size of each size fraction was calculated to be $(18.9 \mathrm{~mm}),(9.5 \mathrm{~mm}),(4.7 \mathrm{~mm})$, $(2.4 \mathrm{~mm})$ and $(1.2 \mathrm{~mm})$, respectively. Each size fraction was crushed in the crusher at different rotation frequencies using 1 $\mathrm{kg}$ of the particular feed size fraction at a time. The frequencies used and the corresponding specific energies are presented in Table 2.

TABLE 2

EXPERIMENTAL FREQUENCIES AND CORRESPONDING SPECIFIC ENERGIES

\begin{tabular}{|c|c|c|c|c|c|}
\hline $\mathrm{rpm}$ & 750 & 1000 & 1500 & 2000 & 2500 \\
\hline $\mathrm{e}=\mathrm{J} / \mathrm{kg}$ & 385 & 685 & 1541 & 2739 & 4279 \\
\hline $\mathrm{e}=\mathrm{kWh} / \mathrm{ton}$ & 0.107 & 0.190 & 0.428 & 0.761 & 1.189 \\
\hline
\end{tabular}

The crushed product of each test was collected and classified in size fractions using the screens of $16,8,4,2,1$, $0.5,0.25,0.125$ and $0.063 \mathrm{~mm}$. The mass distribution of each product is the cumulative mass \% finer than the corresponding screen and is plotted versus the screen size in the same figure for all the specific energies used. From such a figure one may see the effect of the specific energy on the size analysis of the products.

The relative screen size was defined as the ratio of a particular screen used for the product to the upper screen corresponding to the feed fraction used. For example, for the feed size of 16-22.4 mm, the corresponding relative screen sizes used are $(22.4 / 22.4=1), \quad(16 / 22.4=0.714)$, $(8 / 22.4=0.357),(4 / 22.4=0.179)$ and so on, while for the feed size $4-5.6 \mathrm{~mm}$ the corresponding relative screen sizes used are $(5.6 / 5.6=1),(4 / 5.6=0.714),(2 / 5.6=0.357),(1 / 5.6=0.179)$ etc. According to this definition, the cumulative mass \% passing of a product derived from a known feed size, for which a particular specific energy was used, was plotted versus the relative size. In the same figure one can plot the cumulative mass \% passing for all the products derived from all feed sizes used having the same specific energy. This kind of presentation allows one to see the effect of the initial feed size on the size analysis of the products under the same energy impact.

Finally, in order to compare the three different kinds of rocks used for the tests one can plot in the same figure the cumulative mass $\%$ passing for each material using the same feed size and the same specific energy.

\section{EXPERIMENTAL RESULTS}

The cumulative mass \% passing of the products, from the same feed size, produced at different energy inputs is plotted in the same figure versus the screen size. These figures show the effect of energy on the product size. The relative size was defined as the ratio of a screen size of the product to the maximum screen size in the feed. In the next series of figures, the cumulative mass \% passing of the products, for the same energy input, produced from different feed sizes is plotted in the same figure versus the relative size. These figures show the effect of feed size on the size of the product for the same energy input.

\section{A. Crystalline Limestone}

The cumulative mass \% passing a certain screen is plotted in Figure 6 versus the screen size for the same feed size 16$22.4 \mathrm{~mm}$ for different specific energies. Similar figures can be plotted for all feed sizes used, but all of them will show the same trend.

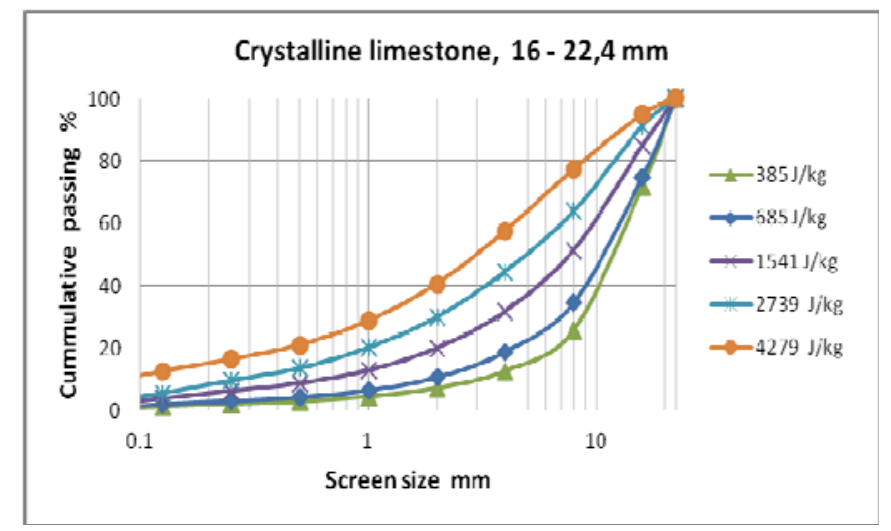

Fig. 6. Crystalline limestone, feed size of 16-22.4 mm, Source (K. Kiskira) [3]

This figure shows that for the same energy input the cumulative mass passing a certain screen is reduced as the screen size decreases. At the same time, one may notice that as the specific energy input increases, the cumulative mass finer increases for the same screen size indicating that the product becomes finer.

Figure 7 presents the cumulative mass \% passing of crystalline limestone products produced under the same energy impact from different feed sizes versus the relative size. 


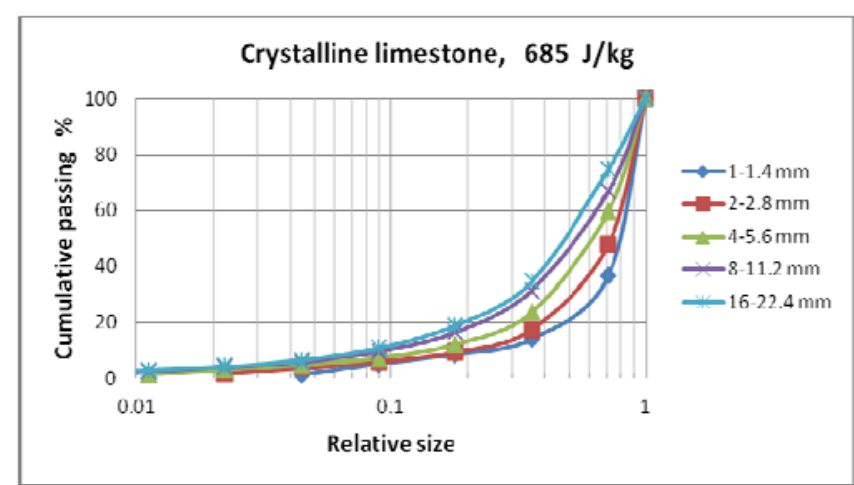

Fig. 7. Crystalline limestone, specific energy of $685(\mathrm{~J} / \mathrm{kg})$

This figure shows again that the cumulative mass of the product of a particular feed size decreases as the relative size decreases. It also shows that for the same energy input of 685 $(\mathrm{J} / \mathrm{kg})$ the cumulative mass passing a certain relative size increases indicating that the coarser particles break faster than the smaller ones.

\section{B. Marly Limestone}

The results corresponding to marly limestone are presented in Figures 8 and 9.

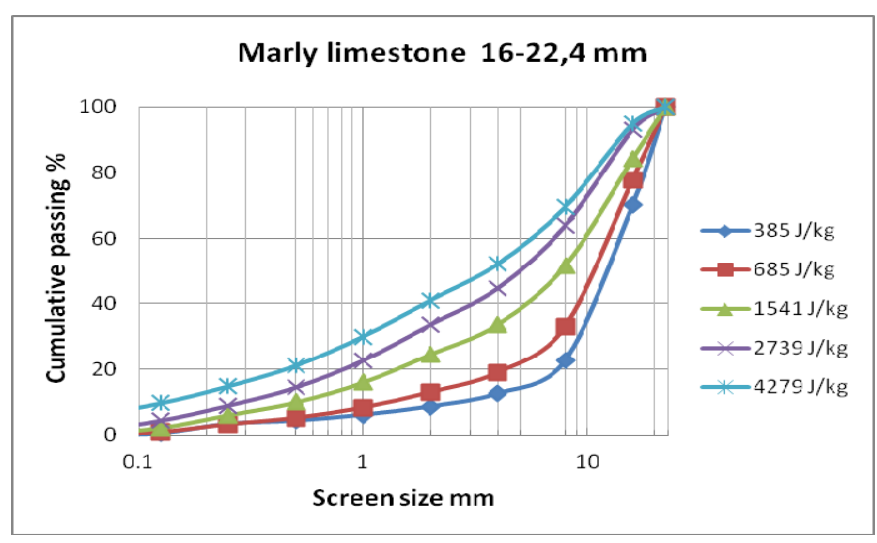

Fig. 8. Marly limestone, feed size of 16-22.4 mm

The results from marly limestone are similar to the ones obtained from crystalline limestone, but at the moment it is not easy to make quantitative comparisons. This is to be done in the following paragraph.

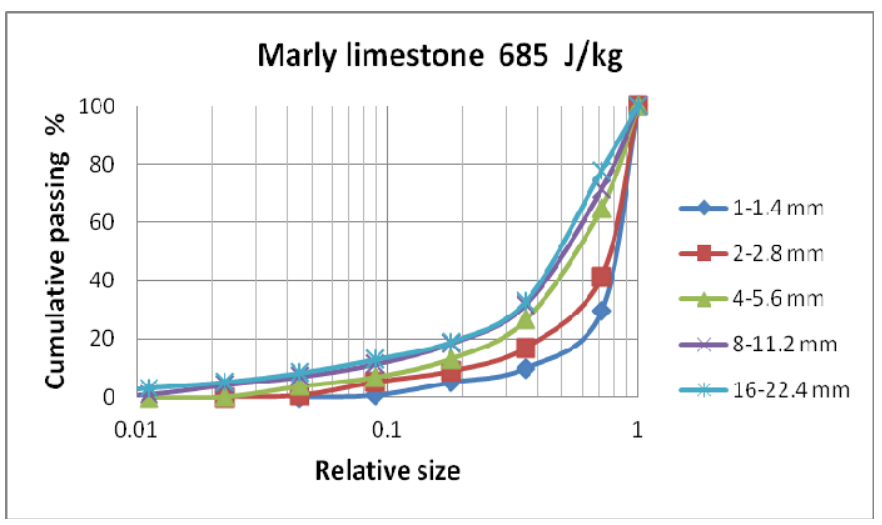

Fig. 9. Marly limestone, specific energy of $685(\mathrm{~J} / \mathrm{kg})$, Source (K. Kiskira) [3]

\section{Serpentine}

The results obtained for serpentine are illustrated in Figures 10 and 11 and are very similar to the ones obtained from the two samples of limestone already tested.

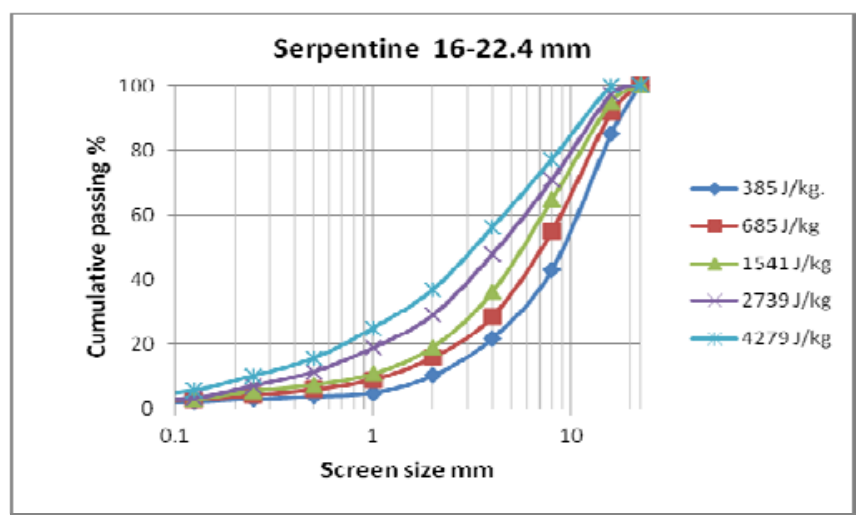

Fig. 10. Serpentine of 1-22.4 mm, Source, (A. Emejulu) [4]

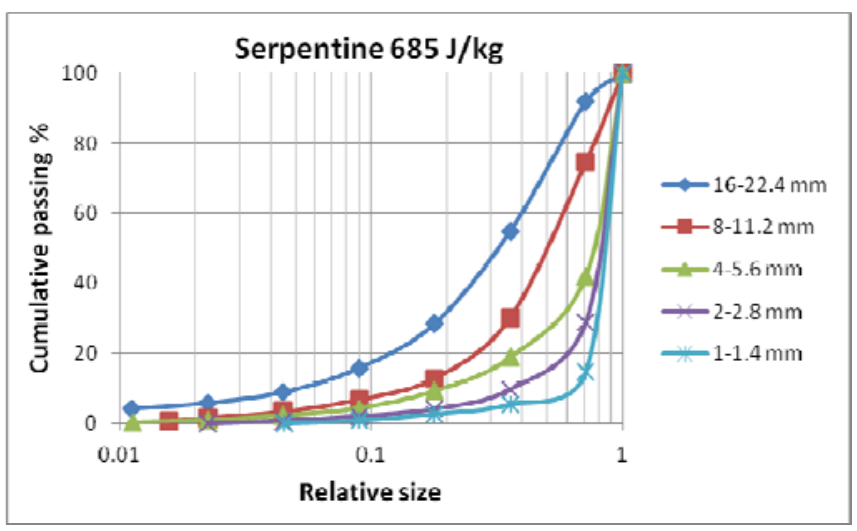

Fig. 11. Serpentine, specific energy of $685(\mathrm{~J} / \mathrm{kg})$

\section{Comparison of the Materials}

The data above show a similar behaviour of the three materials tested. The feed size and the specific energy input are the main factors affecting the size analysis of the products. A comparison of the grindability of the minerals tested is provided below in Figures 12, 13 and 14, where the test conditions are the same for all three materials.

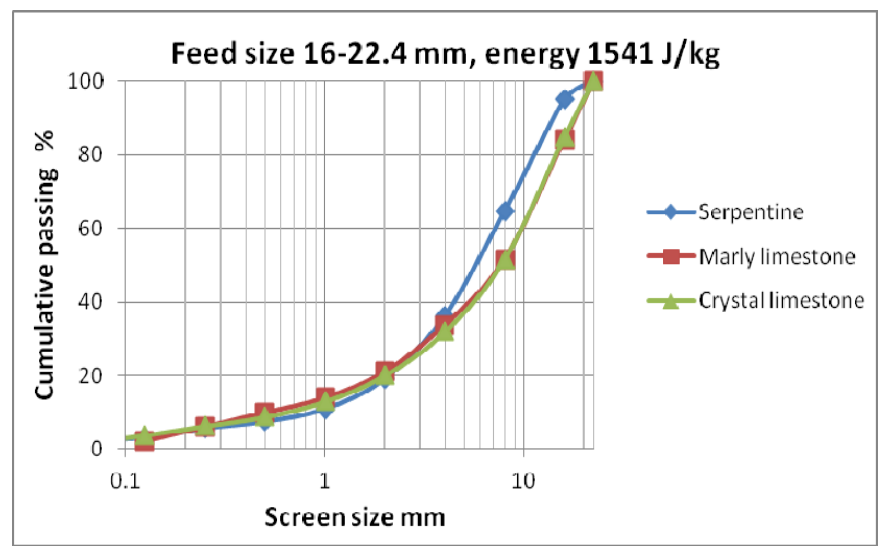

Fig. 12. Comparison of the materials, energy of $1541(\mathrm{~J} / \mathrm{kg})$, feed size of $16-$ $22.4 \mathrm{~mm}$ 
Figure 12 indicates the results at the energy input of 1541 $(\mathrm{J} / \mathrm{kg})$ and feed size of 16-22.4 $\mathrm{mm}$. One may see that the two tested qualities of limestone have almost the same behaviour, while serpentine breaks faster at high size ranges. Figure 13 shows the corresponding results for the same energy input for the feed size of 4-5.6 $\mathrm{mm}$. Here again the two qualities of limestone have almost the same behaviour, while serpentine is more difficult to break at this feed size.

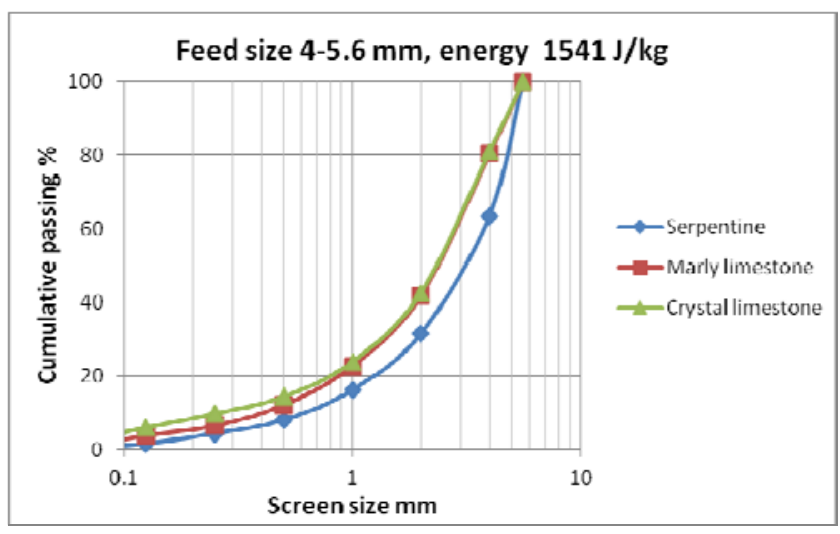

Fig. 13. Comparison of the materials, energy $1541(\mathrm{~J} / \mathrm{kg})$, feed size 4-5.6 mm

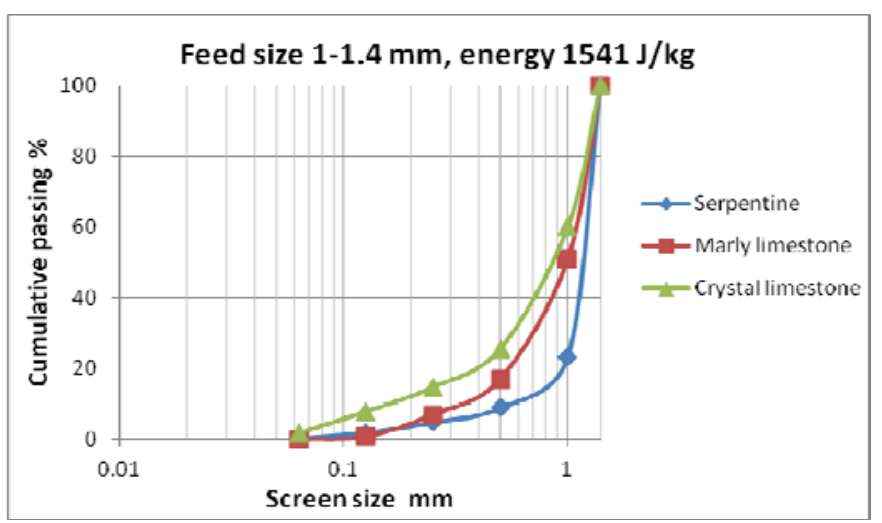

Fig. 14: Comparison of the materials, energy $1541(\mathrm{~J} / \mathrm{kg})$, feed size 1-1.4 mm

These figures show that serpentine breaks easier at coarse feed size, but it becomes harder than the other rocks at finer sizes.

\section{DISCUSSION AND CONCLUSIONS}

The results presented above show a similar behaviour of all three rocks tested, and it can be summarized as follows:

For a given feed size the product is finer as the specific energy increases and this is supported by the results presented in Figures 6, 8 and 10.

For the same specific energy the coarser feed sizes give relatively finer material. This conclusion is possible by using the concept of relative size and the results are presented in Figures 7, 9 and 11.

The comparison of the resistance to breakage or the grindability of the three rocks is shown in Figures 12, 13 and 14, drawn for the same energy input and different feed sizes. These figures show that the behaviour of the rocks differs depending on the feed size. This is more apparent with serpentine, which at coarse feed size breaks easier than the other rocks tested, while at fine feed size it is much more difficult to break. One could explain this particular behaviour comparing the crystal structure of the rocks presented in Figures 3, 4 and 5. The crystalline limestone is a homogeneous material, while serpentine is not. The particles are made of smaller crystals in the form of islands surrounded by a more or less inhomogeneous binder that appears to be weathered and weaker than the healthy crystals. The crystals are harder than the weathered material that binds them together. Consequently, the coarser particles break across the soft binder, which is easier to break than the smaller healthy crystal.

The conclusions made above are more or less qualitative, but one could draw more quantitative ones providing a different treatment of the same results presented in Figures 15, 16 and 17. Each size class of the feed material is presented by its average size, see technical procedure above, and is represented by a different curve in the same figure. Each figure shows the percentage of the material of the feed fraction that has been crushed and has passed to a lower size class as a function of the energy input. From these figures one may read the specific energy required to crush $50 \%$ of the initial feed size to a lower size class. This energy is defined as the breakage energy of the specific size class for one of the rocks tested. The results obtained are presented in Table 3.

TABLE 3

ENERGY-SIZE RELATIONSHIP

\begin{tabular}{|c|c|c|c|}
\hline & \multicolumn{3}{|c|}{ Breakage specific energy, J/kg } \\
\hline $\begin{array}{c}\text { Feed size, } \\
\text { mm }\end{array}$ & $\begin{array}{c}\text { Crystalline } \\
\text { limestone }\end{array}$ & $\begin{array}{c}\text { Marly } \\
\text { limestone }\end{array}$ & Serpentine \\
\hline 1.2 & 1100 & 1500 & 4500 \\
\hline 2.4 & 780 & 950 & 2200 \\
\hline 4.7 & 500 & 450 & 1100 \\
\hline 9.5 & 280 & 310 & 320 \\
\hline 18.9 & 245 & 250 & 230 \\
\hline
\end{tabular}

This table shows that the breakage energy decreases with size ant the relationship is drawn in Figure 18 with a log-log scale. The equations that describe the energy-size relationship are presented in the same figure for each rock tested.

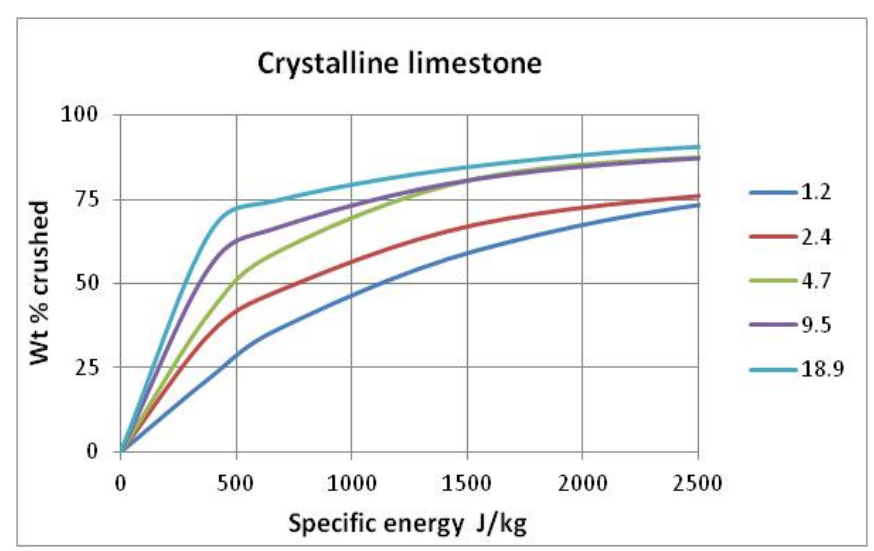

Fig. 15. Breakage of crystalline limestone 


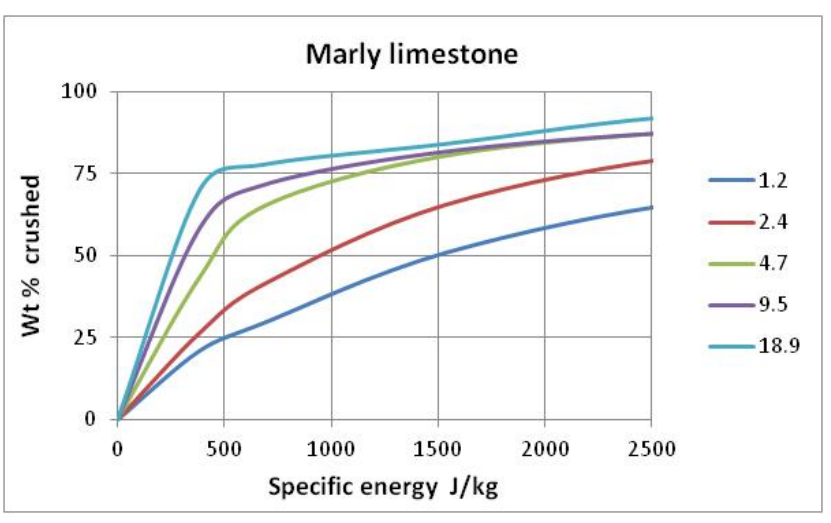

Fig. 16. Breakage of marly limestone

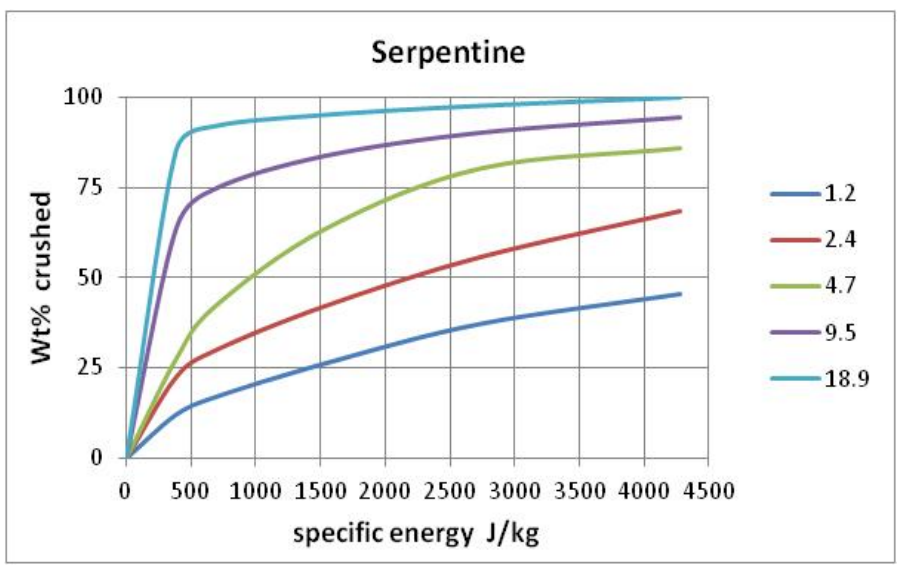

Fig. 17. Breakage of serpentine

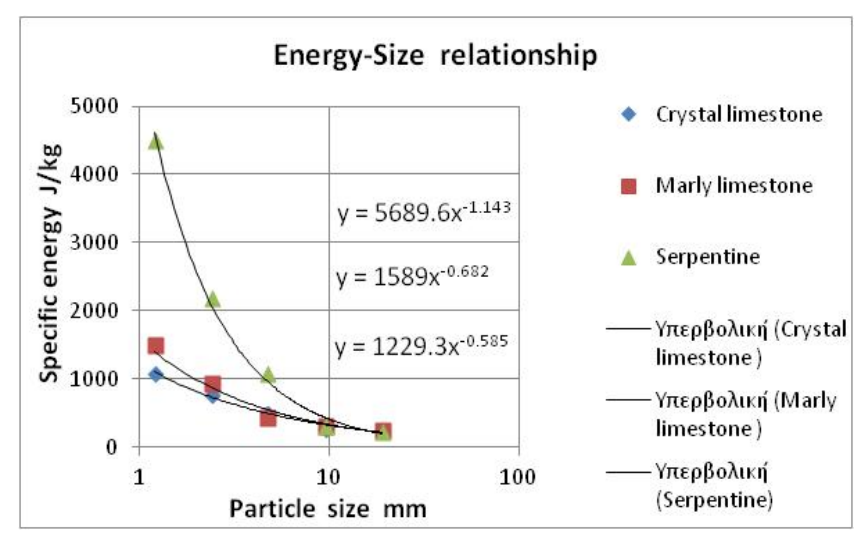

Fig. 18. Energy-size relationship

The equations of the curves that present the energy-size relationship clearly show that the exponent is neither $(-1)$ or $(-$ $0.5)$ as the corresponding theories of Rittinger [5] and Bond [6] suggest, but it can vary as proposed by Charles [7] and Stamboliadis et al. [8].

The final conclusion of this study may be that it presents a centrifugal crusher that gives the possibility to control the kinetic energy of particles, when they crush on a wall, and from the size analysis of the feed and the product to draw a conclusion about the breakage of the material used and to study the energy-size relationship. A suggestion for further study is to derive the mathematical model of the curves presented in Figures 15 to 17 and to calculate the breakage energy using the model to be proposed. A further suggestion for future research is to study inhomogeneous materials, such as serpentine, and probably to find different equations that apply to coarse and fine particles.

\section{REFERENCES}

1. Tavares L. M., King R.P., Single particle fracture under impact load, I.J. Mineral Processing, 1998, Vol. 54, Issue 1, pp. 1-28.

2. Stamboliadis D., Design of a centrifugal crusher for minerals, based on the design of structures, undergraduate thesis, Technological Education Institute of Piraeus, 2013, Greece. (in Greek)

3. Kiskira K., Study of crushing rocks and materials by an improvised centrifugal crusher., undergraduate thesis, Technical University of Crete, 2012, Greece. (in Greek)

4. Emejulu A.C., Crushing of Clay bearing Limestone and Serpentine using a Novel Centrifugal Crusher, postgraduate thesis, IMACS course, 2012, Technical University of Crete, Greece

5. Rittinger P. R. Lehrbuch der Aufbereitungskunde, 1867, Berlin

6. Bond F.C., The third theory of comminution, trans. AIME, Mining Eng. 193, pp 484-494

7. Charles R.J., Energy-Size Reduction Relationships in Comminution, Trans. AIME, Mining Eng., 1957, Vol. 208, 80-88.

8. Stamboliadis E., Emmanouilidis S., Petrakis Ev. (2011), A New Approach to the Calculation of Work Index and the Potential Energy of a Particulate Material, Geomaterials, 2011, 1, 28-32. http://dx.doi.org/10.4236/gm.2011.12005

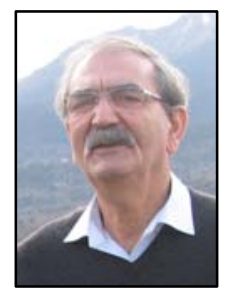

Elias Stamboliadis studied Mining and Metallurgy at the NTUA in Athens (1971). His Master Degree was in Mineral Process Design at the Royal School of Mines, Imperial College, London (1973) and he received his $\mathrm{PhD}$ from McGill University in Montreal (1977). He has worked as the Head of the Research Department and later as a Production Manager at FIMISCO, a magnesite mining company in Greece, (1977-1991) and later as a Processing Plant Director at TVX Gold Hellas (19952000). Since 1992 he has been a Professor of Mineral Processing at the Technical University of Crete. His research interests include comminution, size-energy relationship, mineral liberation, mineral separation by physical methods, and mineral leaching by chemical and biological methods. Environmental protection is always a must for solid and liquid effluents of material processing.

Address: University Campus 73100 Chania, Greece

Phone: +302821037601

E-mail: elistach@mred.tuc.gr

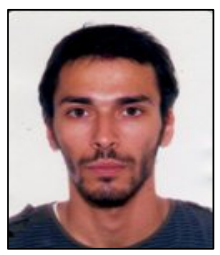

Dimitrios Stamboliadis, Student in Mechanical Engineering at the Technological Education Institute of Piraeus, Greece. Submitted thesis: "Design of a Centrifugal Crusher for Minerals, Based on the Design of Structures. Piraeus, Greece. 2012.

Practical experience:

a) a six-month internship at T.E.M.M.A S.A, an industrial subcontractor specializing in the machining of high precision metal components, Athens, 2010-2011;

b) a Research Assistant at the Technical University of Crete, involved in pelletizing of municipal sewage sludge, Chania, Crete, 2009;

c) a Research Assistant at the Technical University of Crete, constructing air diffusers for a fluidized bed air separator, Chania, Crete, 2008;

d) a Student Trainee during a two-month internship at the maintenance and machining department of Hellas-Gold S.A., Stratoni, Halkidiki, Greece, 2007. Co-author in:

a) "Crushing of Mineral Particles by Control of Their Kinetic Energy" presentation at the $53^{\text {rd }}$ International Scientific Conference of RTU, Riga, Latvia, 2012;

b) "Method of Composting Municipal Sewage Sludge and Other Amorphous Materials" Patent number: 1005997, Athens, Greece.

Address: Asklepiou 37, 16673 Voula, Greece

Phone: +306946976549

E-mail: dstamboliadis@hotmail.com 


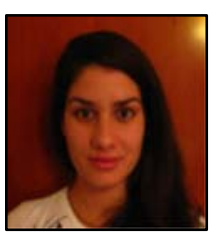

Kyriaki Kiskira studied at the Department of Mineral Resources Engineering, Technical University of Crete in Chania, Greece (2006-2012). Her Master Degree is in Advanced Clay Science (IMACS) at the University of Poitiers in Poitiers, France (2012, ongoing). She has worked as a Production Assistant Engineer at Hellas Gold S.A, a gold mining company in Stratoni, Chalkidiki, Greece (August 2010). Her presentations: Work Practice at Hellas Gold S.A., the paper presented at the Technical University of Crete (2010), and the Bachelor Thesis "The Study of Crushing rocks and Materials by an Improvised Centrifugal Crusher, presented at the Technical University of Crete (2012). She received Scholarship, Performance Award (Technical University of Crete, the years of 2006-2007, 2008-2009 and 2009-2010).

Address: Vlahothanasi 35, Neos Kosmos, 11744, Athens, Greece Phone:+306934789465

E-mail: kirki.kis@gmail.gr

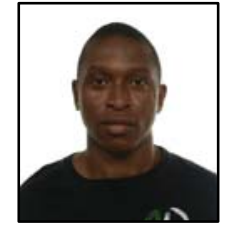

Anthony Chukwudubem Emejulu studied Civil Engineering at Nnamdi Azikiwe University in Nigeria (2002-2007). His Master Degree was International Master in Advance Clay Science (IMACS). Specialization followed: Environment, Soil and Geological Systems, the University of Poitiers, France (2010-2012); Geomaterials and Civil Engineering/Assessment and Processing,

the Technical University of Crete, Greece (2011-2012).

His research paper was Master's Project I - Phenol Removal, Technical University of Crete, Greece, 2011 and the research paper (Master's Project II) - Crushing of Clay Bearing Limestone and Serpentine using a Novel Centrifugal Crusher; the Technical University of Crete, Greece, 2012. His co-authored paper/publication is Crushing of Mineral Particles by Control of Their Kinetic Energy and Phenol Removal from the Water Effluents of Olive Presses.

$\mathrm{He}$ is a member of Erasmus Mundus Alumni, the International Clay Association of the USA and also a member of Civil Engineering Association in the UK.

Address: Mineral Resource Engineering, University Campus

Technical University of Crete, 73100 Chania, Greece

Phone: +30698412630

E-mail: dubememe@yahoo.com

Elias Stamboliadis, Dimitris Stamboliadis, Kyriaki Kiskira, Chukwudubem Emejulu. Minerālu daliṇu drupināšana, kontrolējot to kinētisko enerğiju

Enerğija, kas nepieciešama, lai sadrupinātu kalnu iežu daļiņas, ir viens no svarīgākajiem faktoriem minerālu pārstrādē. Darba autori apraksta centrbēdzes drupinātāju, kas izveidots, lai minerālu daļin̄ām piedotu kontrolējamu kinētisko enerǵiju, pirms to sagraušanas, triecoties pret cietu virsmu, kas ir perpendikulāra to kustības virzienam.

Drupinātāja galvenā detaḷa ir rotējošs disks, kas paātrina daļiņas un piedod tām nepieciešamo īpatnējo enerğiju, pirms tās atdalās no diska un sadrūp, triecoties pret pretī esošo sienu.

Saskaṇā ar izstrādāto matemātisko modeli, īpatnējā enerǵija, kas tiek pievadīta pētāmajām dalinām (enerğija uz masas vienību), ir atkarīga no rotējošā diska diametra un frekvences, bet nav atkarīga no dalinu izmēra. Veicot eksperimentus, izejmateriālu - kristāliskā un merğeḷainā kaļ̧̧akmens, kā arī kalnu ieža serpentīna dažāda izmēra daḷiņām centrbēdzes drupinātājā tika piedots paātrinājums, lai tās iegūtu atšksirīgu ippatnējo enerğiju.

Sadrupinātās daļinas tika frakcionētas pēc to izmēriem. Iegūtie rezultāti parādīja, ka rupjākās daļiņas sadrūp vieglāk, nekā smalkās. Savstarpēji salīdzinot pētīto kalnu iežu sadruptspēju, redzams, ka rupjākās erodēto kalnu iežu daḷinas sadrūp vieglāk, bet tās var būt ļoti izturīgas pret triecienu, samazinoties līdz nelielu veselu kristālu izmēriem. Lielas, bet veselas kaļ̧̧̣akmens dạinnas ir izturīgākas pret sadrupšanu, nekā erodēta serpentīna daḷiņas. Tomēr mazākās serpentīna dalinnas ir grūtāk sadrupināt, nekā vienāda izmēra kaļkakmens daļiņas.

Jebkuram pētītajam materiālam, to sadrupinot līdz mazākai daļiṇu izmēru klasei, atkarībā no pieliktās īpatnējās enerǵijas, var atrast enerǵiju, kas ir nepieciešama, lai sadrupinātu $50 \%$ dalinu no noteikta izmēra klases. Šo enerǵiju definē kā noteikta izmēra daḷinu klases īpatnējo drupināšanas enerğiju. Līkne, kuru veido īpatnējā drupināšanas enerğija, kas attiecināta pret konkrētas izmēru klases vidējo izmēru, parāda enerǵijas - izmēru sakarību, kas ir drupināšanas spējas vienādojums. Eksponenta skaitliskai vērtībai šajā vienādojumā nav jābūt vienādai ar (-1) vai $(-0,5)$, kā tas tiek parasti pieņemts. To apliecina iepriekšējā publikācijā iegūtie dati par iežu drupināšanu ložu dzirnavās.

Turpinot pētījumus, ir jāizstrādā matemātiskais modelis, lai procentuāli aprakstītu dalinu izmēru klasi, kas, materiālam sadrūpot, veido mazāko izmēru klasi, kā pieliktās īpatnējās enerǵijas funkciju. Parametri, kas tiks izmantoti šajā modelī, ļaus novērtēt dažādu kalnu iežu un minerālu sadrupināšanas raksturlielumus.

Элиас Стамболиадис, Димитрис Стамболиадис, Кириаки Кискира, Чуквудубем Эмэюлу. Дробление минеральных частиц, контролируя их кинетическую энергию.

Энергия, необходимая для разрушения частиц горных пород, является важнейшим фактором в переработке минералов. В работе авторы описивают центробежную дробилку, разработанную, чтобы придать минеральным частицам контролируемую кинетическую энергию, перед их разрушением при ударе о твердую поверхность, расположенную перпендикулярно направлению их движения. Основной особенностью дробилки является конструкция ротирующего диска, ускоряющего частицы и придающего им необходимую удельную энергию перед тем, как они отрываются от диска и разрушаются в результате удара об противостоящую стенку.

В соответствии с разработанной математической моделью, удельная энергия, приданная испытуемим частицам (энергия на единицу массы), зависит от диаметра и частоты вращения диска, но не зависит от размеров частиц.

Исходными образцами кристалического известняка, мергеля и серпантина различных размеров было придано ускорение для приобретения частицами различной удельной энергии.

Раздробленные частицы были фракцированны в зависимости от размеров частиц. Полученные результаты показали, что крупные частицы дробятся легче, чем мелкие. Сравнение способности испытуемых образцов горных пород разрушаться показало, что крупные частицы эродированных горных пород разрушаются быстрее, но они могут быть очень ударопрочными при приближении размеров частиц к малым бездефектным кристаллам. Специфически большие, но бездефектные частицы известняка являются более прочными, чем эродированные серпантиновые частицы горных пород. Однако мелкие серпантиновые частицы - более прочные, чем частицы известняка эквивалентных размеров. 
$2013 / 28$

Для всех испытуемых материалов, в зависимости от приданной удельной энергии, раздробленных до размеров, соответствующих мельчайшему классу, может быть найдена энергия, необходимая для разрушения 50\% частиц соответствующего класса размера. Эта энергия классифицируется как удельная энергия разрушения частиц материалов определенного класса размеров. Кривая, характеризующая отношение удельной энергии разрушения к среднему размеру частиц определенного класса размеров, отражает взаимосвязь между энергией разрушения и размерами раздробленных частиц, и определяет производительность центробежной дробилки. Численное значение экспоненты уравнения не должно быть равной (-1) или (-0.5) как это обыкновенно принято. Это подтверждается предидущей работой, рассматривающей дробление горных пород в шаровой мельнице.

В дальнейшей работе рекомендуется разработать математическую модель, процентуально отражающую классы размеров частиц, раздроблунных на частицы более мелких классов, как функцию от приданной удельной энергии. Параметры, использованные в этой модели, позволят оценить эффективность дробления различных горных пород и минералов. 